historian who has focused on gender discrimination her entire career, and has been leading the Center of Excellence Women and Science at the GESIS Leibniz Institute for the Social Sciences in Cologne, Germany, since 2006. "The idea of women as mothers who stay at home to take care of children is deeply ingrained in German society," she says.

In many ways, she says, the picture of today's German woman is still defined by the clear gender roles of past generations, including those of the National Socialists, who demanded women focus on family, children and the household. But Dalhoff stresses gender bias among decision makers is still pivotal to how German women are treated.

When East Germany fell under Communist rule, during which equal opportunity for men and women was emphasized, women started to enter careers that were traditionally the reserve of men. Although few made it into leadership positions, one of the era's most prominent women is Angela Merkel, Germany's chancellor, who grew up in East Germany and earned a $\mathrm{PhD}$ in quantum chemistry (see 'Leading the way').

Germany's federal constitution guarantees women equal rights and gives the state a responsibility to foster equality and remove hurdles related to gender. And yet a spokesperson for the Federal Ministry for Education and Research (BMBF) told Nature that: "Scientific examinations found structural barriers in this field which have had a negative effect on the careers of women in sciences." According to many female scientists, these hurdles can range from a lack of childcare facilities to straight up sexism and discrimination by superiors who favour men.

\section{FIXING THE PROBLEM}

To fix this, the government and private organizations have launched a wide range of initiatives to foster women's talent and try to put them on an equal footing with men, targeting all age ranges from schoolgirls up to female university professors. For example, 'Komm, mach MINT' is a nationwide network of women in science, technology, engineering and mathematics (STEM) that works to raise awareness of scientific careers and encourage schoolgirls to choose a STEM field. Prizes

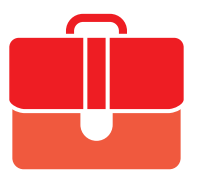

\footnotetext{
A $€ 5.4$ MILLION INITIATIVE AIMS TO INCREASE THE PROPORTION OF WOMEN IN SENIOR POSITIONS FROM 19\% TO 24\% BY 2020.
}

and stipends such as the Women Techmakers Scholars Program from technology giant Google encourage women to become role models in computer sciences. Female students are eligible for grants such as the Henry Ford grant for women who study engineering. And during the nationwide 'Girls' Day', STEM companies, research facilities and universities give schoolgirls a chance to learn about STEM careers. Since 2016, publicly traded companies in Germany have been required to meet a quota of $30 \%$ women in their board of directors.

Anatomist Heike Kielstein, who researches obesity and natural killer cells (a type of immune cell) at the University Hospital in Halle (Saale), says that she's seen first-hand how little flexibility there is when it comes to, for example, letting young mothers mark papers from home. Kielstein herself has two teenage sons and two teenage stepsons. "If I feel a scientist is being discriminated against because she's a woman, I will speak up," she says.

One solution to tackling structural inequality is to implement the cascade model, also known as the leaky pipeline, under which the ratio of women to men should remain the same as both move up the career ladder. But that is far from being achieved: in 2017, 50.8\% of university students but only $24.1 \%$ of fulltime professors were women.

\section{POSITIVE DISCRIMINATION}

The Professorinnenprogramm is an initiative that was started by the BMBF to support female professors across all higher-education disciplines, from sciences to the arts. Initiated in 2008 , it has provided more than $€ 300$ million in funding to universities that pledge to work on improving gender equality. To be eligible, a university has to submit a proposal detailing planned genderequality initiatives, which range from better childcare facilities to mentoring programmes. If the proposal is accepted, the federal and provincial government will fund the salary of one or more professorships. The condition: women have to be hired for the funded professorship and the freed-up budget has to be used to put the gender-equality initiatives into action.

This programme, the BMBF says, has helped to increase the percentage of female professors across all fields from just $15.2 \%$ in 2006 to $23.4 \%$ in 2016. Between 2008 and 2018, more than 500 professorships were awarded to women. It's a generous incentive for universities to be proactive about gender equality, a spokesperson from BMBF says. "Furthermore, the project contributes to a change in scientists' and university culture and gender-neutral interactions with one another, free of discrimination."

The third phase of the programme will run from 2018 to 2022 with a budget of $€ 200$ million and a maximum of $€ 165,000$ in funding per female professorship per year.

Dalhoff, whose group evaluated the last

\section{Q\&A \\ LEADING THE WAY}

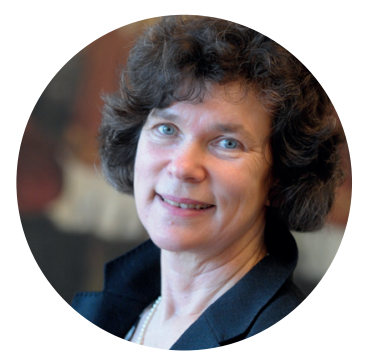

In 2011, Beate Schücking became the first female head of Leipzig University in its 600-year history. A total of 967 men preceded her. Born in 1956, Schücking earned her medical degree at the age of 24 and her first professorship at 33 , and is a specialist in maternal and child health research and psychosocial medicine. She was re-elected in 2017. What was the scientific landscape like for women when you started out? In the 1970s, not as many women were beginning a scientific career in Germany as today. The ratio of female medicine students to men back then was below $30 \%$. The general idea, also dominant in my family, was women can study, but once married, they should exclusively focus on their family.

\section{What have been the biggest changes since then? \\ Having a family and a scientific career is seen as compatible. Still, conditions for female scientists are harder than for their male colleagues. Long-lasting, outdated role models don't change that fast. Often, women still have to choose between children and their career, and run the risk of having neither. But now, you also see male scientists who are single parents.}

\footnotetext{
Why does Germany still have one of the lowest ratios of female professors? We have enough programmes to support women in their careers. It's now time to improve society's appreciation of women in leadership positions. We have very few women managing Germany's publicly traded companies, and high-ranking, female politicians are likely to trigger more controversy and criticism compared with men. It takes time to change the role models that have dominated Germany for so long. It's a step by step process to change people's
} mindsets. D.H. 